\title{
Cloning and secretory expression of functional diisopropyl- fluorophosphatase (DFPase) in Bacillus subtilis
}

\author{
Ali Ahmadizad Firouzjaei ${ }^{1,2}{ }^{\mathbb{D}}$, Shamsozzoha Abolmaali ${ }^{\mathbb{D}}$, Samaneh Khodi $^{\circledR}{ }^{\circledR}$, Hossein Aghamollaei ${ }^{\circledR}$, Ali Mohammad \\ Latifi $^{3 *}$, Morteza Mirzaei ${ }^{(\mathbb{D}}$ \\ 'Department of Biotechnology, School of Advanced Technologies in Medicine, Shahid Beheshti University of Medical \\ Sciences, Tehran, Iran \\ ${ }^{2}$ Department of Biology, Faculty of Basic Science, Semnan University, Semnan, Iran \\ ${ }^{3}$ Applied Biotechnology Research Center, Baqiyatallah University of Medical Sciences, Tehran, Iran \\ ${ }^{4}$ Chemical Injuries Research Center, Systems Biology and Poisonings Institute, Baqiyatallah University of Medical Sciences, \\ Tehran, Iran
}

*Corresponding Author: Alimohammad Latifi, Applied Biotechnology Research Center, Baqiyatallah University of Medical Sciences, Tehran, Iran. Tel: +982188617711, Email: amlatifi290@gmail.com

\begin{abstract}
Background and aims: Synthetic organophosphates (OPs) inhibit acetylcholinesterase resulting in the accumulation of acetylcholine, failure of organs, and eventually death. Diisopropyl-fluorophosphatase (DFPase) is one of the OPs degrading enzymes that has broad substrate from OPs. In this study, for the first time, the secretory expression of DFPase in Bacillus subtilis was investigated in order to accelerate the biodegradation rate of OPs.

Methods: DFPase gene was amplified using polymerase chain reaction (PCR) from the $\mathrm{pET} 28$-inaV/N-dfpase plasmid. The PCR product was subcloned in the pWB980 plasmid. Competent B. subtilis WB600 were transformed with recombinant plasmid. SDS PAGE technique was used to study the expression of protein secreted in superrich medium.

Results: Appearance of the 946 bp band in agarose gel after digestion of transformed plasmid confirmed the presence of DFPase gene in this construct. Approximately, $35 \mathrm{kDa}$ protein band was shown in culture medium after incubating at $35^{\circ} \mathrm{C}$ for 72 hours and $150 \mathrm{rpm}$. Measurement of enzyme's activity was done by monitoring the release of fluoride from diisopropyl fluorophosphate (DFP), using ion-meter. Results showed that enzyme's activity was $3333 \mathrm{U} / \mathrm{L}$.

Conclusion: Bacillus subtilis is a suitable host for production of secretory and active form of DFPase.

Keywords: Organophosphorus compounds, B. subtilis WB600, Secretory expression, DFPase
\end{abstract}

Received: 14 May 2019, Accepted: 26 October 2020, ePublished: 30 June 2021

\section{Introduction}

Organophosphorus compounds were widely used in the world as an insecticide and additives in oil and plastic industry from the end of World War II (1). Excessive and repeated use of these compounds resulted in contamination of soil and water ecosystems with these compounds across the world (2,3). Organophosphates (OPs) were introduced for the first time in 1850. Over the years, Long and Roger Vaughan introduced insecticides and the synthesis of the first OP included P-F bonds that were in diisopropyl fluorophosphate (DFP). OPs can effectively enter the human body through oral, inhalation, and also by reacting with tyrosine residues in keratins in skin epithelium and are effective on multiple biological systems of the human body as the most common cause of poisoning (4). Nervous system is one of the major biological systems of animals on which OPs are effective and impair its function in many ways. The most important and effective way to disrupt the functioning of the nervous system is to inhibit the cholinesterase (5). Cholinesterase is divided into two main groups in vertebrates: acetylcholinesterase and pseudocholinesterase or butyrylcholinesterase (this enzyme is synthesized by liver and is found in plasma, pancreas, heart, and brain. Serine is a hydrolase with the capability of hydrolysis of esters with acetylcholine, succinylcholine, and mivacurium. Its half-life is 8 to 12 days in serum and is an alpha-globulin) (6-8).

A number of pesticides or their metabolites like DDT or pyrethroid act as disturbing elements in human or animal endocrine glands (9-11). Other critical systems such as the immune system $(12,13)$, pancreas $(14,5)$, liver $(16)$, and blood system (5) are also influenced by organophosphorus compounds.

Strategies such as combustion, burying in depth and remote areas are of the most basic and convenient methods of detoxification of organophosphorus compounds, but it is seriously opposed by scientists because it causes poisonous gas emissions in the air and pesticide leakage into the ground and water (4). Chemical analysis through some reactions such photolysis, 
hydrolysis, dehalogenation, oxidation, and reduction of organophosphorus compounds is also the other form of non-biodegradation. Some pesticides are chemically capable of being hydrolyzed in alkaline water or alkaline soils (17). Several species of bacteria with insecticide hydrolysis properties are separated from the wastewaters of plants that are able to hydrolyze chlorpyrifos (18). Several enzymes have been identified which are able to analyze organophosphorus compounds, like carboxylesterases, organophosphorus hydrolase, organophosphorus acid anhydride, paraoxonase-1, aminopeptidase $\mathrm{P}$ (a metalloprotein in Escherichia coli), phosphonate ester hydrolase, and diisopropyl-fluorophosphatase (DFPase) (19). In the meanwhile, DFPase enzyme is one of the enzymes regarded in biodegradation of organophosphorus compounds with features such as high stability, broad substrate specificity, and performance in a wide range of $\mathrm{pH}$. This enzyme was achieved by Francis Hoskin in 1966 for the first time from the heart and brain of squid Loligo vulgaris (20). Calcium ions are required for function of DFPase. This enzyme can degrade P-F bond in fluorophosphate and hydrolyzes soman and sarin. DFPase hydrolyzing activity for paraoxon is lower than PF substrate (4). Accordingly, this study aimed to evaluate the secretory production of DFPase enzyme by using secretory system of Bacillus subtilis, which a good option to ease purification and high production.

\section{Materials and Methods}

All chemical materials were biological grade and prepared from Merck and Sigma or Calbiochem.

\section{Bacterial strains, plasmids, and enzymes}

The sequence encoding DFPase gene from Loligo vulgaris (GenBank accession no. Q7SIG4) was designed by Gene designer and CLC sequence Viewer and synthesized (by ShineGene Co.) in plasmid pET-28a (+) (Novagen, USA). B. subtilis WB600 and pW980 vector (from Institute Pasteur, Iran) were used as host cell and expression vector, respectively. The pW980 vector contains P43 promoter that leads to the high level expression of protein without inducer.

\section{Construction of pWB980-dfpase Plasmid}

The pWB980-dfpase was constructed to produce DFPase extracellulary by $B$. subtilis WB600. The dfpase was amplified from pET-28a(+)inaV-N-dfpase vector (21) using forward primer 5'AATAAGCTTATGGAGATTCCAGTTATCGAA3' and reverse primer 5'ATTGGATCCTTAAAAAATACCAAATTTTAACGT 3' (the HindIII and BamHI sites, respectively, are underlined). Reaction mixture containing $0 / 15 \mu \mathrm{g}$ of plasmid, $5 \mu \mathrm{L}$ of $10 \times$ Pfu buffer, $4 \mu \mathrm{L}$ dNTP Mix (10 mM each), $1.25 \mu \mathrm{L}$ of each primer $(10 \mathrm{pmol})$, and $0.6 \mu \mathrm{L}$ high fidelity enzyme PCR was prepared. The total volume of reaction reached to $50 \mu \mathrm{L}$ by DDW. Polymerization was performed by following program: initial denaturation: $94^{\circ} \mathrm{C}$ for 30 seconds, followed by 30 cycles at $94^{\circ} \mathrm{C}$ for 30 seconds, $60^{\circ} \mathrm{C}$ for $30 \mathrm{sec}$, and $72^{\circ} \mathrm{C}$ for 1 minute. Program was finalized at $72^{\circ} \mathrm{C}$ for 5 minutes. Agarose gel electrophoresis followed by UV-transilluminator visualization was utilized for observation of PCR products. Amplified $d$ fpase fragment was HindIII (Thermo) and BamHI (Thermo) digested and ligated into similarly digested pW980 vector to generate plasmid pW980-dfpase.

\section{Transformation and screening}

Bacillus subtilis was transformed using optimized method as described in a previous study (22). In this method, an antibacterial peptide with a concentration of $1 \mu \mathrm{g} / \mathrm{mL}$ is applied to increase transformation efficiency. This peptide can permeate the membrane and lead to enhancement in plasmid transformation. Transformants able to hydrolyze organophosphorus compounds were screened on Mineral Salts Medium (MSM) containing $0.1 \mathrm{~g} / \mathrm{L} \mathrm{NaCl}$ (Merck), $0.2 \mathrm{~g} / \mathrm{L} \mathrm{KCl}$ (Merck), $0.5 \mathrm{~g} / \mathrm{L}$ (NH4) SO $_{4}$ (Merck), $50 \mathrm{mg} / \mathrm{L}$ $\mathrm{CaCl}_{2} \cdot \mathrm{H}_{2} \mathrm{O}$ (Merck), $0.2 \mathrm{~g} / \mathrm{L} \mathrm{MgSO}_{4} \cdot 7 \mathrm{H}_{2} \mathrm{O}$ (Merck), and $20 \mathrm{mg} / \mathrm{L} \mathrm{MgSO}_{4} .7 \mathrm{H}_{2} \mathrm{O}$ (Merck) supplemented with 50 $\mu \mathrm{g} / \mathrm{mL}$ chlorpyrifos (99.5\% purity, Sigma) and $10 \mu \mathrm{g} / \mathrm{mL}$ kanamycin (Sigma) (23). Untransformed B. subtilis was used as control sample. Cloning was confirmed by PCR and digestion.

\section{SDS-PAGE}

To investigate the expression of DFPase, a preculture of $B$. subtilis WB600 harboring pW980-dfpase was grown overnight at $35^{\circ} \mathrm{C}$ in super-rich medium (24) supplemented with kanamycin $(10 \mu \mathrm{g} / \mathrm{mL})$. Then, $50 \mathrm{~mL}$ of the same culture medium was inoculated with this fresh culture and incubated at $150 \mathrm{rpm}$ and $35^{\circ} \mathrm{C}$ for 12,24 , $36,48,72,96$, and 108 hours. Cells were harvested using centrifuge at $8000 \mathrm{rpm}$ for 5 minutes and the supernatant was investigated using SDS-PAGE (sodium dodecyl sulphate-polyacrylamide gel electrophoresis) analysis. SDS-PAGE was performed on both $15 \%$ and $10 \%$ running gel with a $15 \%$ stacking gel referred to the method of Laemmli (25).

\section{Assessment and Tracing of the DFPase Activity}

The DFPase activity was measured by fluoride release monitoring from DFP developed by Cheng DeFrank (26). Following the procedures, fluoride ion-selective electrodes (ISE) of Metrohm 781 Ion Meter was used and calibrated prior to measurement using standard fluoride solutions. Next, $1 \mathrm{~mL}$ of bacterial supernatant was added to $10 \mathrm{~mL}$ reaction medium $(500 \mathrm{mM} \mathrm{NaCl}, 50 \mathrm{mM}$ BisTris propane, $0.1 \mathrm{mM} \mathrm{MnCl} 24 \mathrm{H}_{2} \mathrm{O}$ ) and incubated for 1 minute. Then, DFP in a total concentration of $3.0 \mathrm{mM}$ was added to the reaction. The amount of fluoride released was measured 10 min after enzyme interaction with DFP. One unit of DFPase activity is defined as catalyzing the release of 0/0189 ppm F- per minute using a modified MichaelisMenten equation (27). 
Results

Transformation of construct to B.subtilis

The results of the construction of recombinant plasmid are shown in Figure 1.

The results showed the growth of recombinant strain on the medium containing kanamycin, which indicates the accuracy of transformation because this ability is related to pWB980-dfpase plasmid. For the detection of recombinant bacteria expressing DFPase, the colonies harboring the recombinant plasmid were inoculated on the plates containing MSM with $50 \mathrm{mg} / \mathrm{L} \mathrm{DFP}$ as the sole source of carbon and energy, which was only observed in five out of seven transformants.

The recombinant plasmid pWB980/dfpase was confirmed by PCR and double digestion methods and analyzed on agarose gel electrophoresis. The bands between 900 and 1000 bp related to dfpase nucleotide sequence (945 bp) are shown in Figure 2.

No band was observed in B. subtilis harboring pW600 as control sample. Appearance of the 946 bp band after digestion of transformed plasmid confirmed the presence of $d f p s e$ gene in this construct (Figure 3).

\section{SDS-PAGE analysis}

The extracellular proteins of native B. subtilis WB600 and B. subtilis harboring WB600/dfpase are shown by SDSPAGE after 48 hours and 72 hours (Figure 4). A sharp band about $35 \mathrm{kDa}$ related to secretory DFPase was only observed in the lanes related to the recombinant plasmid. The band observed after 72 hours was sharper than the band obtained after 48 hours.

\section{Enzyme activity to degrade DFP}

The supernatant solution was used to investigate the enzyme activity to degrade P-F bond in DFP. In the supernatant of B. subtilis carrying DFPase gene, $0.241 \mathrm{ppm}$ fluoride ion was detected. Since this assay was performed

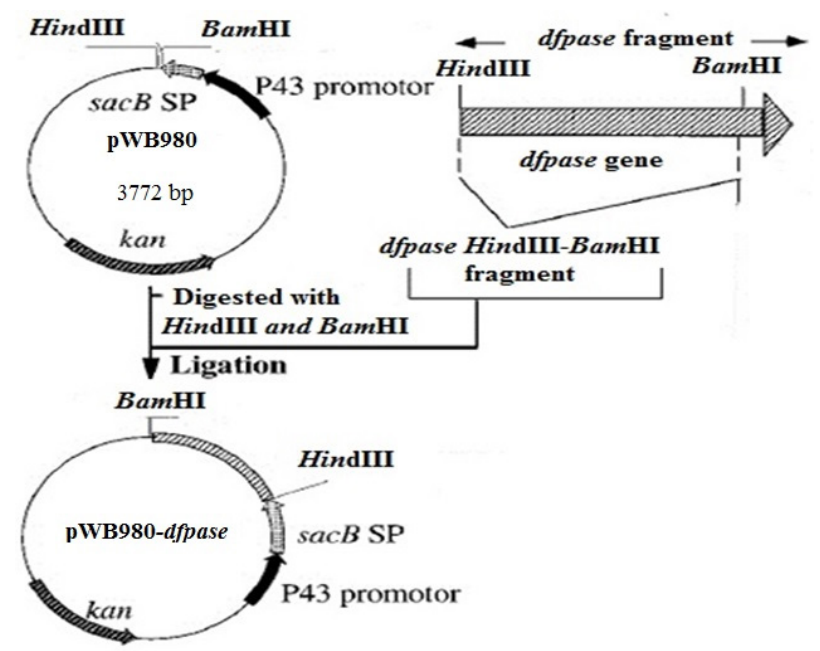

Figure 1. Construction of pWB980-dfpase plasmid. The dfpase gene was inserted to the pWB980 plasmid between the HindIII and $\mathrm{Bam} \mathrm{HI}$ restriction site. kan: kanamycin resistance marker. sacB SP: secretory signal sequence.

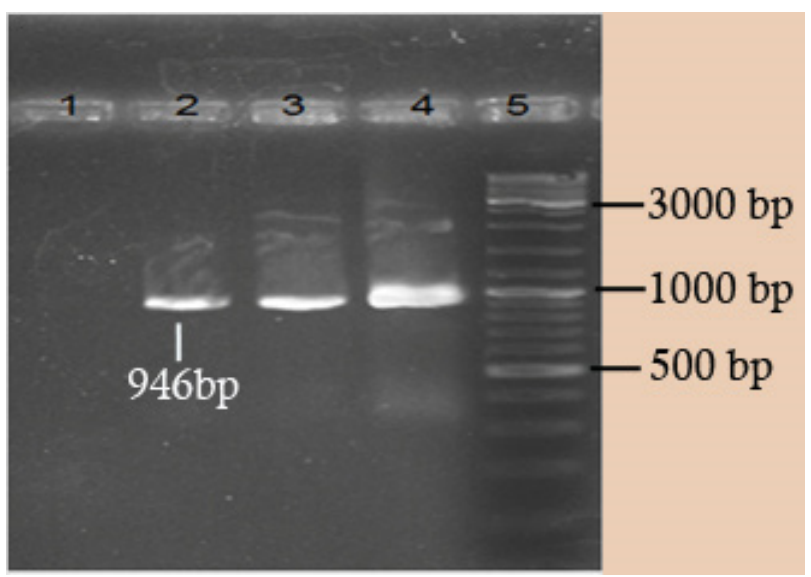

Figure 2. Agarose gel electrophoresis analysis of PCR products. Lane 1, PCR product from pWB980 plasmid. Lane 2, 3, 4, PCR product from pWB980-dfpse plasmid. Lane 5, DNA marker SM0333 (Thermo).

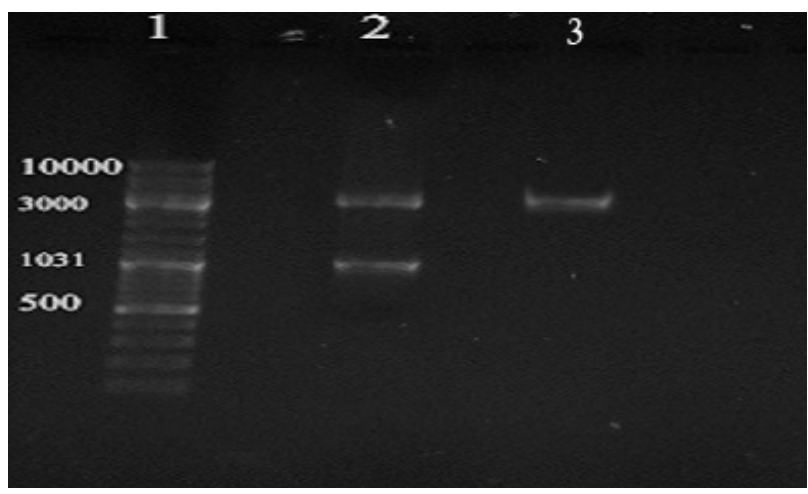

Figure 3. Agarose gel electrophoresis analysis of the double digestion of plasmid. Lane 1: DNA marker SM0333. Lane 2: Double digestion of pWB980-dfpse plasmid with BamHI and HindIII. Lane 3: Recombinant pWB980-dfpse without digestion.

by crude supernatant which has low concentration of enzyme, this activity is desirable (Figure 5) according to the following formula:

$$
R=C_{\Delta}-C_{\text {substrate }}\left[\frac{E_{1}}{V_{1} x T}\right]
$$

(R: enzyme's activity/ $\min , \mathrm{C}_{\Delta}$ : Ion concentration/min, $\mathrm{C}_{\text {Substrate: }}$ : Spontaneous breakup rate

E: Volume of sample $(\mathrm{ml}), \mathrm{V}_{1}: 1000 / \mathrm{V}, \mathrm{V}$ : Total volume, T: Time),

Enzyme's activity was achieved 3333 U/L.

\section{Discussion}

Organophosphorus compounds create many problems for humans by inhibiting the acetylcholinesterase enzyme. Hence, in recent decades, scientists have been seeking for detoxification of these compounds. Among the proposed methods, enzymatic degradation is considered as one of the best methods because it is eco-friendly (28). DFPase is regarded as one of the enzymes with high stability and broad substrate specificity among the enzymes used for detoxification of organophosphorus pesticides. The gene of this enzyme was extracted from the brain of 


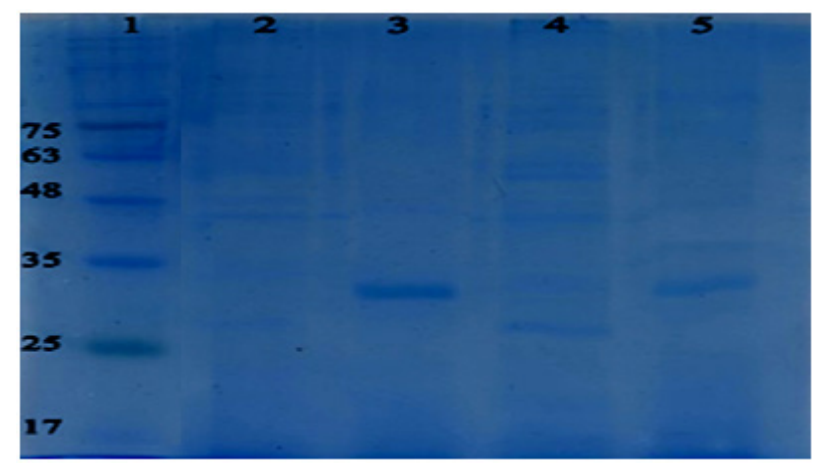

Figure 4. SDS-PAGE Analysis of the Extracellular DFPase. Lane 1: Protein marker Cinnagen PR911654, Lane 2: The extracellular proteins of native $B$. subtilis WB600 after 72 h. Lane 3: The extracellular proteins of $B$. subtilis pW600/dfpase after $72 \mathrm{~h}$, which shows the band about $35 \mathrm{kDa}$ related to secretory DFPase. Lane 4: The extracellular proteins of native B. subtilis WB600 after 48 hours. Lane 5: The extracellular proteins of B. subtilis pW600/dfpase after 48 hours, which shows the band about $35 \mathrm{kDa}$ related to secretory DFPase.

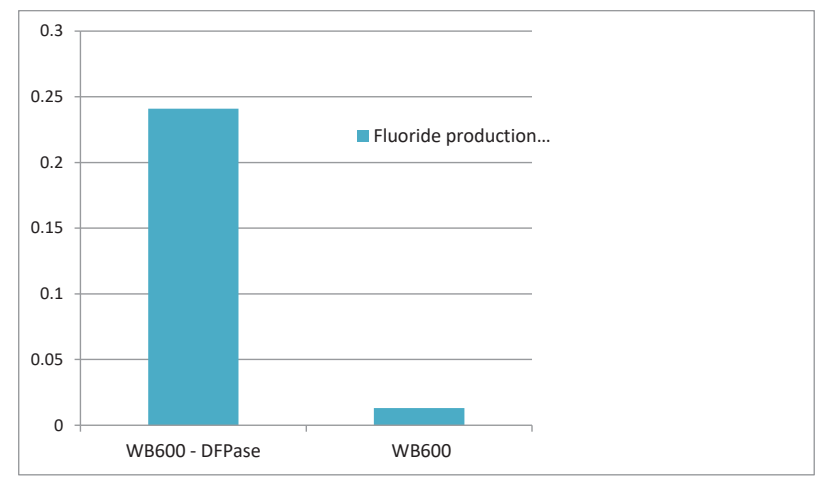

Figure 5. Released fluoride detected by ion selective electrode in $B$. Subtilis WB600 and B. subtilis WB600/dfpase supernatant cultures after 72 hours incubation.

squid (Loligo vulgaris). This enzyme breaks down large dangerous organophosphorus compounds, but its special feature is more for DFPase. The intracellular production of this enzyme in E.coli was reported by Judith Hartleib and Heinz Ru " terjans in E. coli bacteria (20). In this case, the promoter causes overexpression of this enzyme, but the overexpression of this enzyme was accompanied by formation of inclusion body, and E. coli RNA polymerase system with low temperature culture was used to solve this problem. Although this approach showed lower expression as compared to the previous method, it did not have the problem of intracellular body formation, and enzymes were found soluble in cytoplasmic space and purification was easier; therefore, it is a better approach to produce the enzyme $(29,30)$. Promoter leakage can be noted as the main disadvantages of this method. Also, the enzyme is produced intracellularly in this case. Since organophosphorus compounds, as the substrate of the enzyme, are in environment and out of the reach of the enzyme, it makes the direct use of this bacterium difficult for detoxification of these compounds. Its other disadvantage is that enzyme separation needs complex and costly steps. The study of secretory expression is one of the ways to reduce the steps of combined production by overcoming the membrane barrier. If $E$. coli is used in the case, secretory production of enzyme will confront with some problems such as the formation of wrong disulfide bonds and accumulation in periplasmic space as intracellular bodies and the presence of outer membrane as a restriction in enzyme departure. Proteolytic degradation and production of small amounts of product are among other problems of these methods (31). These problems in E. coli can be solved using genetic manipulation, as well as the use of L-form bacteria, no cell wall or cell wall deficient bacteria, labeling secretory protein with a sign sequence, and protein binding with other secretory protein. But the point of interest in this case is the low production of secretory protein (30); moreover, genetic manipulations affect the bacterial growth and production of B. subtilis is suitable for this purpose because it is a non-pathogenic bacterium able to secrete products extracellularly and into the culture medium when the enzyme is produced as an extracellular secretory enzyme (32). The enzyme can be secreted in the culture medium with minimal changes. In this case, the substrate can be easily available for enzyme and the enzyme can function better. In addition, purification process takes place easier in this method. B. subtilis is useful for extracellular production of recombinant proteins such as pullulanase, lipase LipA, streptavidin, and PHA depolymerase A (PhaZ5). In the detoxification of organophosphorus compounds by enzyme secreted into the surrounding bacteria, it can be directly used for detoxification of organophosphorus compounds by optimizing the context of enzyme function. This means that hopes to direct detoxification of OPs increase through the use of this bacterium. Also, 27 kinds of protease were identified in the membrane, cell wall, and culture medium in the study of B. subtilis genome; this reduces the quality of enzyme production in natural strains. Some strains were engineered to overcome this problem that lacks important proteases. In a study, six genes responsible for the synthesis of proteases, including protease A, subtilisin, extracellular protease, metalloprotease, bacillopeptidase $\mathrm{F}$, and natural protease $B$ were turned off by the process of genetic engineering in order to further protect the produced proteins (33). Results indicated only $0.32 \%$ of extracellular protease activity compared to the normal type. In this study, the expression system of B. subtilis WB600 was used to extracellularly express the enzyme. Plasmid PWB980 was used as an expression vector in B. subtilis WB600. PWBs are plasmids derived from PUB110; the gene cassette containing $\mathrm{sacB}$ regulatory region, $\mathrm{sacB}$ signal sequence, and TEM $\beta$-lactamase coding sequence are conjugated to it and the enzyme produced by the sequence is secreted outside the cell. In this study, the target gene was under the control of promoter $\mathrm{P} 43$. This promoter is a great promoter for expression of different enzymes. In a study to compare the expression of beta-galactosidase and staphylokinase 
enzymes under the promoters of aprE, amyE, and p43, the results indicated the higher power of promoter $\mathrm{p} 43$ in expressing these two enzymes. The promoter has the ability to continuously and strongly express its under-control gene and is an overlapping promoter which is expressed in both logarithmic and inertia phases continuously (34). Secretory expression of MPH enzyme in the host strain WB800 has shown that mpd gene is expressed under the promoter in both logarithmic and inertia phases (35). SacB signal sequence (nprB), as a peptide, is responsible for taking the protein out of the cell (36). In this work, the peptide was used as a signal secreted outside the cell. This peptide is cut during protein exit from the cell membrane and the enzyme is secreted out as separated from this peptide. In this state, protein is present in the culture medium as a pure protein and there is no need for additional purification steps in secretory expression by E. coli. In this case, the enzyme can act better. Optimal time for protein secretory expression is different for different proteins in B. subtilis. For example, the optimal time for secretory protein production was reported $32 \mathrm{~h}$ by Cook (37), and in the study by Xiao-Zhou Zhang et al., the optimal time for expression of MPH enzyme was 96 hours (35). In this study, bacteria were cultured in a quite rich medium at $35^{\circ} \mathrm{C}$ at $24,48,72$, and 96 hours. As seen in Figure 4, the optimum time to produce the enzyme was 72 hours. Probably, the rate of inactivated proteases plays a role in the increase of enzyme retention time, and consequently production increase. ISE (ion selective electrode) method using ION Meter (Metrohm 781) was used to investigate the DFPase activity. There are other methods of measuring such as titration of fluoride ion, spectroscopy, and gas chromatography; but ISE method has advantages such as high speed and precision, low cost, and high sensitivity compared to other methods. Another advantage of this method is that ions are easily measurable in water and other solutions (38).

\section{Conclusion}

The secretory expression led to production of soluble and active form of DFPase in $B$. subtilis. These bacteria are a suitable host for recombinant expression of secretory proteins. After optimization, WB600 can be a desirable host for high yield production of DFPase.

\section{Acknowledgements}

The study protocol was approved by Baqiyatallah University of Medical Sciences, Iran (Code: 91001180). The authors would like to thank all colleagues in the Applied Biotechnology Research Center of Baqiyatallah Medical Sciences University for their sincere collaboration.

\section{Authors' Contributions}

AA.F: performed the experiments and wrote the manuscript draft; S.A: designed the study; S.K: performed the experiments; H.A: analyzed data and revised the manuscript; M.M: analyzed data; and A.L: designed the study and revised the manuscript. All authors approved the final draft of the manuscript.

\section{Conflict of Interests}

The authors declare that there is no conflict of interest regarding the publication of this article.

Ethical Considerations

This study was approved by the Research Ethics Committee of Baqiyatallah University of Medical Sciences (Code: IR.BMSU. REC.1395.267).

Funding/Support

None to be declared.

References

1. Songa EA, Okonkwo JO. Recent approaches to improving selectivity and sensitivity of enzyme-based biosensors for organophosphorus pesticides: a review. Talanta. 2016;155:289-304. doi: 10.1016/j.talanta.2016.04.046.

2. Triassi M, Nardone A, Giovinetti MC, De Rosa E, Canzanella S, Sarnacchiaro P, et al. Ecological risk and estimates of organophosphate pesticides loads into the Central Mediterranean Sea from Volturno River, the river of the "Land of Fires" area, southern Italy. Sci Total Environ. 2019;678:741-54. doi: 10.1016/j.scitotenv.2019.04.202.

3. Postigo C, Barceló D. Synthetic organic compounds and their transformation products in groundwater: occurrence, fate and mitigation. Sci Total Environ. 2015;503-504:32-47. doi: 10.1016/j.scitotenv.2014.06.019.

4. Ahmadizad Firozjaei SA, Latifi AM, Khodi S, Abolmaali S, Choopani A. A review on biodegradation of toxic organophosphate compounds. J Appl Biotechnol Rep. 2015;2(2):215-24.

5. Ballantyne B, Marrs TC. Clinical and Experimental Toxicology of Organophosphates and Carbamates. Elsevier; 2017.

6. Abdallah C, Udomtecha D. Pseudocholinesterase activity: determination and interpretation in pediatric anesthesia. Middle East J Anaesthesiol. 2007;19(2):423-8.

7. Gülçin İ, Scozzafava A, Supuran CT, Koksal Z, Turkan F, Çetinkaya S, et al. Rosmarinic acid inhibits some metabolic enzymes including glutathione S-transferase, lactoperoxidase, acetylcholinesterase, butyrylcholinesterase and carbonic anhydrase isoenzymes. J Enzyme Inhib Med Chem. 2016;31(6):1698-702. doi: 10.3109/14756366.2015.1135914.

8. Lockridge O. Review of human butyrylcholinesterase structure, function, genetic variants, history of use in the clinic, and potential therapeutic uses. Pharmacol Ther. 2015;148:34-46. doi: 10.1016/j.pharmthera.2014.11.011.

9. Kojima H, Takeuchi S, Van den Eede N, Covaci A. Effects of primary metabolites of organophosphate flame retardants on transcriptional activity via human nuclear receptors. Toxicol Lett. 2016;245:31-9. doi: 10.1016/j. toxlet.2016.01.004.

10. Şimşek ZÖ, Sevim M, Şimşek Y, Sungur M, Gündoğan K, Güven M. Effects of organophosphate poisoning on the endocrine system in the long term: a pilot study. Erciyes Med J. 2019;41(1):33-6.

11. Brander SM, Gabler MK, Fowler NL, Connon RE, Schlenk D. Pyrethroid pesticides as endocrine disruptors: molecular mechanisms in vertebrates with a focus on fishes. Environ Sci Technol. 2016;50(17):8977-92. doi: 10.1021/acs. 
est.6b02253.

12. Blair A, Ritz B, Wesseling C, Freeman LB. Pesticides and human health. Occup Environ Med. 2015;72(2):81-2. doi: 10.1136/oemed-2014-102454.

13. Harada T, Takeda M, Kojima S, Tomiyama N. Toxicity and carcinogenicity of dichlorodiphenyltrichloroethane (DDT). Toxicol Res. 2016;32(1):21-33. doi: 10.5487/ tr.2016.32.1.021.

14. Polat M. Effects of application of chlorpyrifos ethyl and rose water on rat pancreas. Int Invent Sci J. 2018;2(4):109-16.

15. Yoshida S, Okada H, Nakano S, Shirai K, Yuhara T, Kojima $\mathrm{H}$, et al. Much caution does no harm! Organophosphate poisoning often causes pancreatitis. J Intensive Care. 2015;3(1):21. doi: 10.1186/s40560-015-0088-1.

16. Lari P, Abnous K, Imenshahidi M, Rashedinia M, Razavi $\mathrm{M}$, Hosseinzadeh $\mathrm{H}$. Evaluation of diazinon-induced hepatotoxicity and protective effects of crocin. Toxicol Ind Health. 2015;31(4):367-76. doi: 10.1177/0748233713475519.

17. Yadav IC, Devi NL, Syed JH, Cheng Z, Li J, Zhang G, et al. Current status of persistent organic pesticides residues in air, water, and soil, and their possible effect on neighboring countries: a comprehensive review of India. Sci Total Environ. 2015;511:123-37. doi: 10.1016/j. scitotenv.2014.12.041.

18. Bajaj S, Singh DK. Biodegradation of persistent organic pollutants in soil, water and pristine sites by coldadapted microorganisms: mini review. Int Biodeterior Biodegradation. 2015;100:98-105. doi: 10.1016/j. ibiod.2015.02.023.

19. Ramalho TC, de Castro AA, Silva DR, Silva MC, Franca TC, Bennion BJ, et al. Computational enzymology and organophosphorus degrading enzymes: promising approaches toward remediation technologies of warfare agents and pesticides. Curr Med Chem. 2016;23(10):104161. doi: 10.2174/0929867323666160222113504.

20. Hartleib J, Rüterjans H. High-yield expression, purification, and characterization of the recombinant diisopropylfluorophosphatase from Loligo vulgaris. Protein Expr Purif. 2001;21(1):210-9. doi: 10.1006/prep.2000.1360.

21. Latifi AM, Karami A, Khodi S. Efficient surface display of diisopropylfluorophosphatase (DFPase) in E. coli for biodegradation of toxic organophosphorus compounds (DFP and Cp). Appl Biochem Biotechnol. 2015;177(3):62436. doi: 10.1007/s12010-015-1766-0.

22. Heiat M, Aghamollaei H, Moosazadeh Moghaddam M, Kooshki H. Using CM11 peptide as a cell permeable agent for the improvement of conventional plasmid transformation methods in Escherichia coli and Bacillus subtilis. Minerva Biotecnol. 2014;26(3):149-57.

23. Latifi AM, Khodi S, Mirzaei M, Miresmaeili M, Babavalian $\mathrm{H}$. Isolation and characterization of five chlorpyrifos degrading bacteria. Afr J Biotechnol. 2012;11(13):3140-6.

24. Wu H, Wang S, Qiao J, Liu J, Zhan J, Gao X. Expression of HpaGXooc protein in Bacillus subtilis and its biological functions. J Microbiol Biotechnol. 2009;19(2):194-203. doi: 10.4014/jmb.0802.154.

25. Laemmli UK. Cleavage of structural proteins during the assembly of the head of bacteriophage T4. Nature. 1970;227(5259):680-5. doi: 10.1038/227680a0.

26. Cheng TC, DeFrank JJ. Enzymatic Detoxification of Organophosphorus Compounds. Google Patents; 1999.

27. Kapoor M, Rajagopal R. Enzymatic bioremediation of organophosphorus insecticides by recombinant organophosphorous hydrolase. Int Biodeterior Biodegradation. 2011;65(6):896-901. doi: 10.1016/j. ibiod.2010.12.017.

28. Chakrabarty AM. Biodegradation and Detoxification of Environmental Pollutants. CRC Press; 2017.

29. Georgiou G, Segatori L. Preparative expression of secreted proteins in bacteria: status report and future prospects. Curr Opin Biotechnol. 2005;16(5):538-45. doi: 10.1016/j. copbio.2005.07.008.

30. Choi JH, Lee SY. Secretory and extracellular production of recombinant proteins using Escherichia coli. Appl Microbiol Biotechnol. 2004;64(5):625-35. doi: 10.1007/s00253-0041559-9.

31. Tjalsma H, Antelmann H, Jongbloed JD, Braun PG, Darmon E, Dorenbos R, et al. Proteomics of protein secretion by Bacillus subtilis: separating the "secrets" of the secretome. Microbiol Mol Biol Rev. 2004;68(2):207-33. doi: 10.1128/ mmbr.68.2.207-233.2004.

32. Heydari A, Moosazadeh Moghaddam M, Aghamollaei $\mathrm{H}$, Yakhchali MB, Bambaee B, Latifi AM, et al. Cloning and expression of the Bacillus pumilus F3 lipase gene into Bacillus subtilis and determining of comparative expression level between native and recombinant enzyme. New Cellularand Molecular Biotechnology Journal. 2013;3(9):67-73. [Persian].

33. Wu XC, Lee W, Tran L, Wong SL. Engineering a Bacillus subtilis expression-secretion system with a strain deficient in six extracellular proteases. J Bacteriol. 1991;173(16):4952-8. doi: 10.1128/jb.173.16.4952-4958.1991.

34. Kim JH, Hwang BY, Roh J, Lee JK, Kim K, Wong SL, et al. Comparison of PaprE, PamyE, and PP43promoter strength for $\beta$-galactosidase and staphylokinase expression in Bacillus subtilis. Biotechnol Bioprocess Eng. 2008;13(3):313. doi: 10.1007/s12257-007-0102-0.

35. Zhang XZ, Cui ZL, Hong Q, Li SP. High-level expression and secretion of methyl parathion hydrolase in Bacillus subtilis WB800. Appl Environ Microbiol. 2005;71(7):41013. doi: 10.1128/aem.71.7.4101-4103.2005.

36. Song Y, NikoloffJM, Zhang D. Improving protein production on the level of regulation of both expression and secretion pathways in Bacillus subtilis. J Microbiol Biotechnol. 2015;25(7):963-77. doi: 10.4014/jmb.1501.01028.

37. Cook LKN. Optimizing culturing conditions for Bacillus subtilis. South African Avocado Growers' Association Yearbook. 1996;19:54-8.

38. Ahmadizad Firozjaei SA, Khodi S, Latifi AM, Abolmaali S. The comparison of enzyme assay methods in the degradation of organophosphorus compounds using Spectroscopy, FPLC and ISC techniques. New Cellularand Molecular Biotechnology Journal. 2016;6(23):33-8. [Persian]. 